\title{
Resistance gene pool to co-trimoxazole in non-susceptible Nocardia strains
}

\author{
Sylvia Valdezate*, Noelia Garrido, Gema Carrasco, Pilar Villalón, \\ María J. Medina-Pascual and Juan A. Saéz-Nieto
}

Servicio de Bacteriología and Taxonomía, Centro Nacional de Microbiología, Instituto de Salud Carlos III, Madrid, Spain

\section{OPEN ACCESS}

Edited by:

Peter Mullany,

University College London, UK

Reviewed by:

Carlos F. Amábile-Cuevas,

Fundación Lusara, Mexico

Ashima Kushwaha Bhardwaj,

Indian Institute of Advanced

Research, India

*Correspondence:

Sylvia Valdezate

Servicio de Bacteriología

and Taxonomía, Centro Nacional de Microbiología, Instituto de Salud Carlos III, Carretera

Majadahonda-Pozuelo Km 2,200,

Majadahonda, 28220 Madrid, Spain svaldezate@isciii.es

Specialty section:

This article was submitted to

Antimicrobials, Resistance and Chemotherapy,

a section of the journal

Frontiers in Microbiology

Received: 12 February 2015

Accepted: 12 April 2015

Published: 28 April 2015

Citation:

Valdezate S, Garrido N, Carrasco G,

Villalón P, Medina-Pascual MJ and Saéz-Nieto JA (2015) Resistance gene pool to co-trimoxazole in non-susceptible Nocardia strains.

Front. Microbiol. 6:376.

doi: 10.3389/fmicb.2015.00376
The soil-borne pathogen Nocardia sp. causes severe cutaneous, pulmonary, and central nervous system infections. Against them, co-trimoxazole (SXT) constitutes the mainstay of antimicrobial therapy. However, some Nocardia strains show resistance to SXT, but the underlying genetic basis is unknown. We investigated the presence of genetic resistance determinants and class 1-3 integrons in 76 SXT-resistant Nocardia strains by PCR and sequencing. By $E$ test, these clinical strains showed SXT minimum inhibitory concentrations of $\geq 32: 608 \mathrm{mg} / \mathrm{L}$ (ratio of $1: 19$ for trimethoprim: sulfamethoxazole). They belonged to 12 species, being the main representatives Nocardia farcinica (32\%), followed by N. flavorosea (6.5\%), N. nova (11.8\%), N. carnea (10.5\%), N. transvalensis $(10.5 \%)$, and Nocardia sp. (6.5\%). The prevalence of resistance genes in the SXTresistant strains was as follows: sul1 and sul2 93.4 and $78.9 \%$, respectively, dfrA(S1) 14.7\%, blaTEM-1 and blaZ 2.6 and 2.6\%, respectively, VIM-2 1.3\%, aph(3')-IIla 40.8\%, ermA, ermB, mefA, and $m s r D 2.6,77.6,14.4$, and $5.2 \%$, respectively, and tet(O), tet $(M)$, and tet $(L) 48.6,25.0$, and 3.9\%, respectively. Detected amino acid changes in GyrA were not related to fluoroquinolone resistance, but probably linked to species polymorphism. Class 1 and 3 integrons were found in 93.42 and $56.57 \%$ strains, respectively. Class 2 integrons and sul3 genes were not detected. Other mechanisms, different than $d f r A(S 1), d f r D, d f r F, d f r G$, and $d f r K$, could explain the strong trimethoprim resistance shown by the other 64 strains. For first time, resistance determinants commonly found in clinically important bacteria were detected in Nocardia sp. sul1, sul2, $\operatorname{erm}(\mathrm{B})$, and tet $(\mathrm{O})$ were the most prevalent in the SXT-resistant strains. The similarity in their resistome could be due to a common genetic platform, in which these determinants are co-transferred.

Keywords: Nocardia species, co-trimoxazole, antimicrobial resistant determinants, integrons

\section{Introduction}

Nocardia sp. are branching, aerobic actinomycetes found in soil and water, but which have an increasingly recognized role in human disease - a consequence of improvement in their isolation from immunocompromised patients. Indeed, these opportunistic bacteria mainly infect patients with deficient cell-mediated immunity (Minero et al., 2009; Ambrosioni et al., 2010; Welsh et al., 2013). Cutaneous infections are more prevalent in immunocompetent patients, while pulmonary and disseminated infections are more prevalent in the immunosuppressed patients 
(Brown-Elliott et al., 2006; Minero et al., 2009). Delays in diagnosis, a consequence of the absence of specific signs and symptoms, are associated with the progression to disseminated disease and recurrence. In such cases, prolonged antimicrobial treatment is required (Ambrosioni et al., 2010).

Traditionally, nearly all forms of nocardiosis have been treated with co-trimoxazole (trimethoprim/sulfamethoxazole or SXT), either alone or in combination with minocycline, amikacin, or $\beta$-lactams, depending on the organ involved, the severity of infection, and the presence of comorbidities (Ambrosioni et al., 2010; Welsh et al., 2013). SXT inhibits the enzymes involved in two consecutive steps of bacterial folic acid metabolic pathway, i.e., dihydropteroate synthetase (DHPS) and dihydrofolate reductase (DHFR; Huovinen, 2001).

The recognition of resistance to sulfonamide in Nocardia sp. is controversial (Deresinski, 2012). Great differences in the prevalence of sulfonamide resistance have been documented within countries, e.g., Figure 1 of 42 and $2 \%$ have been reported from the USA. These discrepancies have been related to methodological differences and to difficulties in visually determining minimum inhibitory concentrations (MICs) by the broth microdilution (Uhde et al., 2010; Brown-Elliott et al., 2012). In our experience of identifying Nocardia submitted from across Spain, this type of resistance is seen in a reduced number of strains (less than 4\%).

Descriptions of resistance determinants in Nocardia $\beta$-lactamases - or possible determinants - second gyrase B, an extra copy of rpoB-, detected by partial or whole genome sequencing (Laurent et al., 1999; Poirel et al., 2001; Vera-Cabrera et al., 2013), led us to examine, in clinical strains strongly resistant to SXT, the diversity of acquired antimicrobial resistance determinants commonly detected in clinical and environmental bacteria and the presence of integrons as vehicles of the resistance gene recruitment.

\section{Materials and Methods}

\section{Bacterial Strains and Identification}

Seventy six clinical Nocardia strains belonging to 12 species were selected according to their high SXT MIC values $(\geq 32: 608 \mu \mathrm{g} / \mathrm{ml})$. These strains were isolated from patients with signs and symptoms of bacterial infection in 40 locations of 27 Spanish provinces between 2007 and 2013. All strains were identified by $16 \mathrm{~S}$ rRNA partial and full sequencing (RodriguezNava et al., 2006). The sequences were compared with those deposited in the GenBank and leBIBi databases and returned similarities of $\geq 99.6 \%$ with the type species strains (except for five strains that could be identified only at the genus level) according to previously used cut-off for this genus (Petti et al., 2008).

The clinical samples were taken as part of standard patient care and also for this purpose, the bacterial strains were sent to a public national reference laboratory for their identification. This study focused on bacteria and no identifiable human data were used, therefore ethical approval was exempted.

\title{
no. of SXT- resistant Nocardia strains
}

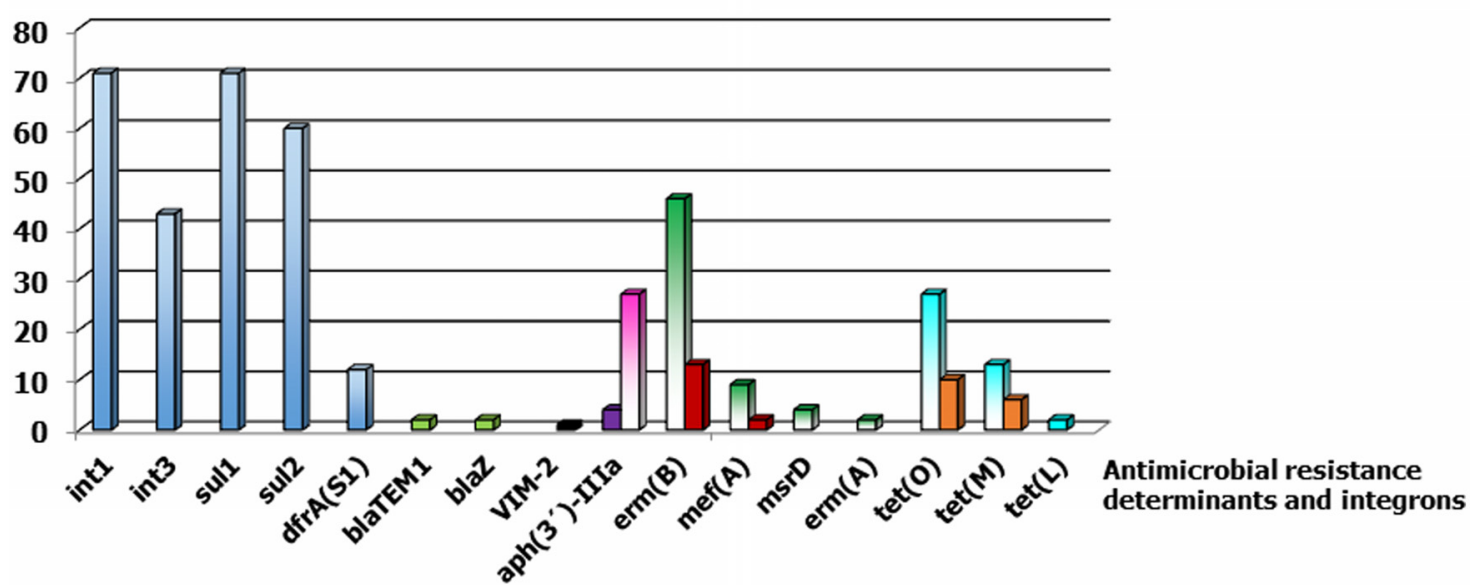

Co-trimoxazole, sulfonamide, and trimethoprim resistant strains (76 strains)

Amoxicillin-clavulanic acid resistant strains (39 strains)

Imipenem susceptible strains (66 strains)

Amikacin resistant strains (9 strains)

Erythromycin resistant strains (58 strains)

Minocycline resistant strains (57 strains)

\author{
Amikacin susceptible strains (67 strains) \\ - Erythromycin suceptible strains (18 strains) \\ - Minocycline suceptible strains (19 strains)
}

FIGURE 1 | Antimicrobial resistance determinants detected in SXT-resistant Nocardia strains considering their susceptibilities to the other studied antimicrobials. The number of strains for each category and agent were showed between brackets. 


\section{Antimicrobial Susceptibility Testing}

The Nocardia cultures were incubated during $48-72 \mathrm{~h}$ at $37^{\circ} \mathrm{C}$. The colonies were swabbed from blood agar plate, using a sterile swab and transferred to $4.5 \mathrm{ml}$ of sterile water. To each flask, 5 -mm sterile glass beads (5-7) were added and repeatedly vortexed, allowing clumps to settle (Clinical Laboratory Standards Institute [CLSI], 2011). The final inoculum was adjusted to a 1.0 McFarland. MICs were determined by $E$ test (BioMerieux, Marcy-l'Étoile, France) onto $150 \mathrm{~mm} \mathrm{MH} \mathrm{Blood} \mathrm{agar} \mathrm{plates,}$ with maximum of five strips for each plate (Glupczynski et al., 2006). The tested agents were: SXT, amoxicillin/clavulanic acid, cefotaxime, imipenem, amikacin, tobramycin, ciprofloxacin, erythromycin, minocycline, sulfonamides, trimethoprim, and linezolid. The MICs were read after $48 \mathrm{~h}$ of incubation at $37^{\circ} \mathrm{C}$ (or after $72 \mathrm{~h}$ if growth was weak; Glupczynski et al., 2006). The MIC was defined as the lowest concentration of antimicrobial to inhibit visible growth, except in case of haziness where $80 \%$ of inhibition was considered. Resistance was recorded according to CLSI interpretative criteria (Clinical Laboratory Standards Institute [CLSI], 2011); intermediate values were categorized as resistant.

\section{Detection of Genes for Antibiotic Resistance and Integrases}

The presence of antimicrobial resistance genes and class 1-3 integrons was analyzed by PCR in all 76 SXT-resistant Nocardia strains. Most of the resistance genes were chosen because of the high frequency with which they appear in clinical and environmental bacteria (given in Table 1). On the basis of the gyrA sequence of Nocardia farcinica IFM 10152 (GenBank accession no. AP006618), primers were used that included the quinolone resistance-determining region (QRDR, 74-113 codons, $5^{\prime} \rightarrow 3^{\prime}$ ), i.e., F+61 = CAGCAGGAGATGCAGAACAG, and $\mathrm{R}-619=$ TGTCCAGCGCCCAGTAGAT. PCR products were resolved by electrophoresis on $2 \%$ agarose gels. All obtained products were purified using ExoSAP-IT reagent (GE Healthcare, Piscataway, NJ, USA) following the manufacturer's recommendations, and sequenced by capillary electrophoresis in an ABI Prism 3100 apparatus (Applied Biosystems, Foster City, CA, USA) using the corresponding amplification primers. BLAST software was used to perform identity searches of the GenBank database (http://www.ncbi.nlm.nih.gov).

\section{Nucleotide Sequence Accession Numbers}

The new sequences identified for int1, int3, sul1, sul2, dfrA(S1), blaTEM-1, blaZ, VIM-2, aph(3')-IIIa, gyrA, ermA, ermB, mefA, $m s r D$, tet $(\mathrm{O})$, tet $M$, and tet $L$ were deposited in the GenBank database under accession numbers KM194583-KM194606.

\section{Results}

\section{Distribution and Susceptibilities of SXT-Resistant Nocardia Strains}

The distribution of Nocardia species among the 76 SXT-resistant strains was as follows: $N$. abscessus $(n=1), N$. carnea $(n=8)$, $N$. cerradoensis $(n=1), N$. cyriacigeorgica $(n=5), N$. farcinica $(n=24), N$. flavorosea $(n=5), N$. nova $(n=9), N$. otitidiscaviarum $(n=3), N$. rhamnosiphilia $(n=1), N$. shimofusensis $(n=1), N$. transvalensis $(n=8), N$. veterana $(n=5)$, and Nocardia sp. $(n=5)$. These were isolated from 60 respiratory samples (56 sputum, one broncho-aspirate, three bronchoalveolar lavage), six cutaneous abscess, one ulcer, one catheter, six cerebral abscesses, one liver abscess, and one cardiac prosthesis. By species, Table 2 shows non-susceptibility rates of the highly SXT-resistant Nocardia strains $(n=76)$.

\section{Distribution of Integrons and sul and dfr Genes}

Seventy five strains (98.68\%) harbored class 1 and/or class 3 integrons (Su et al., 2006; Ishikawa, 2011). Class 1 integrons were more frequently detected than class 3 integrons $[93.42 \%(71 / 76)$ vs. $56.57 \%(43 / 76)$ ]. The simultaneous presence of class 1 and 3 integrons was seen in $42.10 \%(32 / 76)$ of strains. There was no correlation between species and the absence of class 3 integrons (except in $N$. nova, in which $7 / 9$ strains lacked such integrons). High-level sulfonamide resistance is a consequence of the presence of sul1-sul3 (plasmid-borne variants of DHPS; Byrne-Bailey et al., 2009; Gosia et al., 2009), and sul genes were found in 74 strains (97.36\%): 71 strains (93.42\%) had sul1, and $60(78.94 \%)$ had sul2. Both genes were found in 57 strains (75.0\%). No class 2 integrons or sul3 genes were detected in any of the SXT-resistant strains.

Of the 71 strains carrying sul1, 69 also carried intI1, and 39 also carried intI3. Of the 60 strains carrying sul2, 56 also carried intI, and 34 also carried intI3. All the strains were fully resistant to trimethoprim (MICs $>32 \mathrm{mg} / \mathrm{L})$. When screening was performed for the trimethoprim-insensitive $d f r$ genes (known to be horizontally transferable in Gram-positive organisms; Dale et al., 1995; Perreten et al., 2005; Cattoir et al., 2009; Argudín et al., 2011; López et al., 2012), i.e., $d f r A(S 1), d f r D, d f r F, d f r G$, and $d f r K, d f r A(S 1)$ was detected in 12 strains belonging to eight species; no other $d f r$ gene was detected. The deduced $d f r$ proteins for 11 strains were identical to those of Staphylococcus epidermidis ATCC 12228 (NP_764674) and Listeria monocytogenes (AGU67290). One strain of N. farcinica showed a deduced Dfr protein with 24 changes compared to that encoded by $d f r A(S 1)$.

\section{$\beta$-Lactamases and Metallo- $\beta$-Lactamases}

Two types of $\beta$-lactamase gene were detected. The first, $b l a_{\text {TEM-1, }}$, was found in one strain of $N$. farcinica (isolated from a granuloma, with AMC, CTX, and IMP MICs of 32,4 , and $0.5 \mathrm{mg} / \mathrm{L}$, respectively), and in one of $N$. nova (isolated from sputum and with corresponding MICs of 16, 4, and $2 \mathrm{mg} / \mathrm{L}$ ). The second, blaZ, was found in one strain of $N$. veterana (isolated from sputum and with corresponding MICs of 32, 2, and $0.03 \mathrm{mg} / \mathrm{L}$ ) and in one of $N$. flavorosea (isolated from sputum and with corresponding MICs of 32, 0.15, and $0.012 \mathrm{mg} / \mathrm{L}$ ).

No other $\beta$-lactamase genes, such as $a m p C, b l a_{\mathrm{CMY}-2}$, and bla $a_{\mathrm{OXA}}$ were found (Bou and Martínez-Beltrán, 2000; Frye et al., 2006; Henriques et al., 2006b). Primers pairs were also designed on the basis of the FAR-1 and AST-1 sequences (GenBank nucleotide nos. AF024601 and AF279904; Laurent et al., 1999; 
TABLE 1 | Overview of antimicrobial resistance genes and integrons screened and detected (in bold) in the high-level SXT-resistant Nocardia strains.

\begin{tabular}{|c|c|c|c|}
\hline $\begin{array}{l}\text { Antibiotic resistance } \\
\text { group }\end{array}$ & Encoded enzymes & Target gene(s) or region & Reference \\
\hline Integrase genes & $\begin{array}{l}\text { Class } 1 \text { integrase } \\
\text { Class } 2 \text { integrase } \\
\text { Class } 3 \text { integrase }\end{array}$ & $\begin{array}{l}\text { int1 } \\
\text { int2 } \\
\text { int3 }\end{array}$ & $\begin{array}{l}\text { Su et al. (2006) } \\
\text { Su et al. (2006), Ishikawa (2011) } \\
\text { Ishikawa (2011) }\end{array}$ \\
\hline \multicolumn{4}{|l|}{$\begin{array}{l}\text { Folate pathway } \\
\text { inhibitors }\end{array}$} \\
\hline Sulfonamide resistance & Dihidropteroate synthetases (DHFS) & $\begin{array}{l}\text { sul1 } \\
\text { sul2 } \\
\text { sul3 }\end{array}$ & $\begin{array}{l}\text { Gosia et al. (2009) } \\
\text { Gosia et al. (2009) } \\
\text { Byrne-Bailey et al. (2009), Gosia et al. } \\
\text { (2009) }\end{array}$ \\
\hline Trimethoprim resistance & Dyhidrofolate reductases (DHFR) & $\begin{array}{l}\text { dfrA(S1) } \\
\text { dfrD, } \\
\text { dfrF } \\
\text { dfrG, } \\
\text { dfrK }\end{array}$ & $\begin{array}{l}\text { Perreten et al. (2005), Argudín et al. } \\
\text { (2011) } \\
\text { Dale et al. (1995), Cattoir et al. (2009) } \\
\text { Cattoir et al. (2009) } \\
\text { Cattoir et al. (2009), Argudín et al. } \\
\text { (2011) } \\
\text { Argudín et al. (2011), López et al. (2012) }\end{array}$ \\
\hline \multirow[t]{5}{*}{ Betalactam resistance } & Class A betalactamases & $\begin{array}{l}\text { bla }_{\mathrm{TEM}} \\
\text { blaz } \\
\text { blasHV }\end{array}$ & $\begin{array}{l}\text { Chouchani et al. (2012) } \\
\text { Perreten et al. (2005) } \\
\text { Henriques et al. (2006a), Azevedo et al. } \\
\text { (2013) }\end{array}$ \\
\hline & Class B betalactamases ${ }^{a}$ & 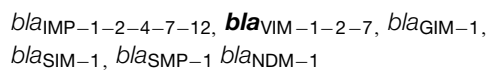 & $\begin{array}{l}\text { Ellington et al. (2007) } \\
\text { Chen et al. (2011) }\end{array}$ \\
\hline & Class $\mathrm{C}$ betalactamases & $\begin{array}{l}\text { ampC } \\
\text { bla }\end{array}$ & $\begin{array}{l}\text { Bou and Martínez-Beltrán (2000) } \\
\text { Frye et al. (2006) }\end{array}$ \\
\hline & Class D betalactamases & $\begin{array}{l}\text { oxa-1, oxa-2, oxa-3, oxa-4, oxa-7, oxa-10, } \\
\text { oxa-11, oxa-13, oxa-14, oxa-15, oxa-16, } \\
\text { oxa-17, oxa-19, oxa-21, oxa-28, oxa-30, } \\
\text { oxa-31, oxa-32, oxa-34, and oxa-35 }\end{array}$ & $\begin{array}{l}\text { Huovinen et al. (1988), Ouellette et al. } \\
\text { (1997), Henriques et al. (2006b) }\end{array}$ \\
\hline & Described Nocardia betalactamases & $\begin{array}{l}\text { FAR-1 } \\
\text { AST-1 }\end{array}$ & $\begin{array}{l}\text { Poirel et al. (2001) } \\
\text { Laurent et al. (1999) }\end{array}$ \\
\hline \multirow{6}{*}{$\begin{array}{l}\text { Aminoglycoside } \\
\text { resistance }\end{array}$} & Aminoglycoside-modifiying enzymes & & \\
\hline & acetyltransferase & aac $\left(6^{\prime}\right)-l e-a p h\left(2^{\prime \prime}\right)-l a$ & Vakulenko et al. (2003) \\
\hline & phosphotransferases & $a p h\left(2^{\prime \prime}\right)-I b, a p h\left(2^{\prime \prime}\right)-l c, a p h\left(2^{\prime \prime}\right)-l d$ & Schmitz et al. (1999) \\
\hline & & $\operatorname{aph}\left(3^{\prime}\right)-I I l a$ & Schmitz et al. (1999) \\
\hline & adenyltransferase & ant $\left(4^{\prime \prime}\right)-\mathrm{la}$, ant $\left(6^{\prime}\right)-\mathrm{la}$ & $\begin{array}{l}\text { Clark et al. (1999), Vakulenko et al. } \\
\text { (2003) }\end{array}$ \\
\hline & $16 \mathrm{~S}$ rRNA methylases & $r m t A, r m t B, r m t C, r m t D$, and $\operatorname{arm} A$ & Doi and Arakawa (2007) \\
\hline \multirow[t]{2}{*}{ Fluoroquinolones } & DNA gyrase mutations & gyrA & This study \\
\hline & $\begin{array}{l}\text { Plasmid-mediated quinolone resistance (PMQR) } \\
\text { Aminoglycoside acetyl-transferase } \\
\text { Efflux pump of major facilitator subfamily }\end{array}$ & $\begin{array}{l}\text { qnrA, qnrB, qnrC, qnrS } \\
\text { aac }\left(6^{\prime}\right)-1 b \\
\text { qepA }\end{array}$ & $\begin{array}{l}\text { Robicsek et al. (2006), Kim et al. (2009) } \\
\text { Cattoir et al. (2007) } \\
\text { Park et al. (2006) } \\
\text { Kim et al. (2009) }\end{array}$ \\
\hline \multirow[t]{4}{*}{ Macrolides } & rRNA adenine N6-methyltransferases & $\operatorname{erm}(\boldsymbol{A}), \operatorname{erm}(\boldsymbol{B}), \operatorname{erm}(C)$ & Sutcliffe et al. (1996) \\
\hline & Esterases & $\operatorname{ere}(\mathrm{A}), \operatorname{ere}(\mathrm{B})$ & Sutcliffe et al. (1996) \\
\hline & MFS efflux proteins & $\boldsymbol{m e f}(\boldsymbol{A} / E), m s r A / B, \boldsymbol{m s r} \boldsymbol{D}$ & $\begin{array}{l}\text { Sutcliffe et al. (1996), Malhotra-Kumar } \\
\text { et al. (2005), Lüthje and Schwarz (2007) }\end{array}$ \\
\hline & Macrolide 2' -phosphotransferases & $\operatorname{mph}(A)$ & Sutcliffe et al. (1996) \\
\hline \multirow[t]{2}{*}{ Tetracycline } & Ribosomal protection protein genes & $\operatorname{tet}(\mathrm{O}), \operatorname{tet}(\mathrm{M})$ & Ng et al. (2001) \\
\hline & Efflux proteins & tet(E), tet(G), tet(K), and $\operatorname{tet}(\mathbf{L})$ & Ng et al. (2001) \\
\hline Linezolid & & 23S rRNA, cfr & $\begin{array}{l}\text { Marshall et al. (2002), Kehrenberg and } \\
\text { Schwarz (2006) }\end{array}$ \\
\hline
\end{tabular}

a Screening only in strains with IMI MIC values $\geq 1 \mathrm{mg} / \mathrm{L}$; ${ }^{\mathrm{b}}$ gentamicin testing was not included.

Poirel et al., 2001); but again, no target sequences were detected. VIM-2 was detected in one N. farcinica strain with no resistance Of the metallo- $\beta$-lactamases (IMP, VIM, SPM-1, GIM-1, SIM-1, to imipenem (isolated from a cerebral abscess; AMC, CTX, and NDM-1; Ellington et al., 2007; Chen et al., 2011) sought, only IMP MICs 1, 4, and $1 \mathrm{mg} / \mathrm{L}$, respectively). 
TABLE 2 | Number and non-susceptibility rates of the highly SXT-resistant Nocardia strains $(n=76)$ by species.

\begin{tabular}{|c|c|c|c|c|c|c|}
\hline $\begin{array}{l}\text { Species (no. of strains) } \\
\text { Antimicrobials }\end{array}$ & $\begin{array}{l}\text { Nocardia farcinica } \\
(n=24)\end{array}$ & $\begin{array}{l}\text { N. carnea } \\
(n=8)\end{array}$ & $\begin{array}{l}\text { N. nova complex } \\
(n=14)^{\mathrm{a}}\end{array}$ & $\begin{array}{l}\text { N. transvalensis } \\
(n=8)\end{array}$ & $\begin{array}{l}\text { Other species }^{b} \\
(n=22)\end{array}$ & $\begin{array}{l}\text { Total } \\
(n=76)\end{array}$ \\
\hline Amoxycillin-clavulanate & $4(16.6 \%)^{b}$ & $6(70.5 \%)$ & $10(71.4 \%)$ & 0 & 19 (86.3\%) & 39 (51.3\%) \\
\hline Cefotaxime & $9(37.5)$ & 0 & $4(28.5 \%)$ & 3 (37.5\%) & 5 (22.7\%) & 21 (27.6\%) \\
\hline Imipenem & 2 (12.0\%) & 0 & $1(7.1 \%)$ & $3(37.5 \%)$ & $6(27.3 \%)$ & $12(15.8 \%)$ \\
\hline Amikacin & 0 & $1(12.5 \%)$ & 0 & $6(75.0 \%)$ & $2(9.1 \%)$ & $9(11.8 \%)$ \\
\hline Tobramycin & 20 (83.3\%) & 0 & 10 (71.4\%) & $7(87.5)$ & $4(18.2 \%)$ & 41 (53.9\%) \\
\hline Ciprofloxacin & $11(45.8 \%)$ & $1(12.5 \%)$ & $12(85.7 \%)$ & $2(25.0 \%)$ & 9 (40.9\%) & 35 (46.0\%) \\
\hline Erythromycin & 21 (87.5\%) & 7 (87.5) & $3(21.4 \%)$ & $8(100 \%)$ & 19 (86.3\%) & 58 (76.3\%) \\
\hline Minocycline & 20 (80.3\%) & $2(25.0 \%)$ & 13 (92.8\%) & $8(100 \%)$ & 14 (63.6\%) & 57 (75.0\%) \\
\hline Linezolid & $2(8.3 \%)$ & 0 & 0 & 0 & $1(4.5 \%)$ & 3 (3.9\%) \\
\hline
\end{tabular}

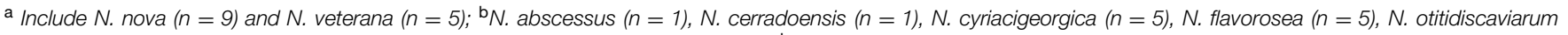

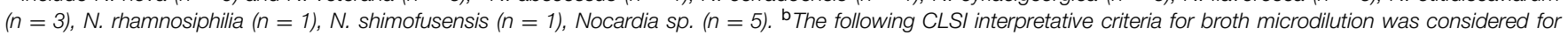

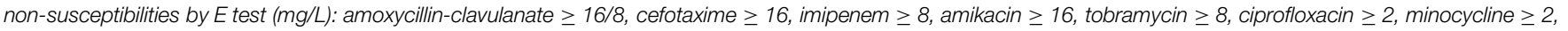
linezolid $\geq 16$. For erythromycin was applied the breakpoint of clarithromycin $\geq 4$.

\section{Aminoglycoside-Modifying Enzymes and 16S rRNA Methylases}

Twenty seven amikacin-susceptible and four non-susceptible strains (susceptibility breakpoint $\leq 8 \mathrm{mg} / \mathrm{L}$ ) harbored the $a p h\left(3^{\prime}\right)$ IIIa determinant that encodes the $3^{\prime}$-aminoglycoside phosphotransferase $\left[\mathrm{APH}\left(3^{\prime}\right)\right]$ responsible for amikacin resistance (Schmitz et al., 1999). The strains belonged to different Nocardia species, and showed MICs to amikacin ranging from 0.12 to $>256 \mathrm{mg} / \mathrm{L}$. No other aminoglycoside-modifying enzyme (AME) genes, i.e., $\operatorname{aac}\left(6^{\prime}\right)-I e-a p h\left(2^{\prime \prime}\right)-I a, a p h\left(2^{\prime \prime}\right)-I b, a p h\left(2^{\prime \prime}\right)-I c, a p h\left(2^{\prime \prime}\right)$ Id, ant (6 $\left.6^{\prime}\right)-I a$, or ant $\left(4^{\prime \prime}\right)$-Ia; Clark et al., 1999; Vakulenko et al., 2003); nor 16S rRNA methylases ( $r m t A, r m t B, r m t C, r m t D$, and armA; Doi and Arakawa, 2007), were detected.

\section{Plasmid-Mediated Quinolone Resistance, gyrA, and other Genes}

None of the strains harbored any of the plasmid-mediated quinolone resistance (PMQR) determinants studied ( $q n r A, q n r B$, $q n r C$, and $q n r$, which encode the pentapeptide repeat proteins that protect type II topoisomerases from quinolone binding; Robicsek et al., 2006; Cattoir et al., 2007; Kim et al., 2009), or the gene for the aminoglycoside acetyltransferase $a a c\left(6^{\prime}\right)-I b-c r$ (which can modify ciprofloxacin; Park et al., 2006), or that for the efflux pump qepA (Kim et al., 2009).

None of the nucleotide changes observed in gyrA would have led to an amino acid sequence with any effect on ciprofloxacin susceptibility or resistance. Within the SXT-resistant N. carnea, $N$. farcinica, $N$. flavorosea, $N$. nova, $N$. transvalensis, $N$. veterana species, the amino acid sequences encoded by their gyr $A$ gene always appeared to be the same, irrespective of ciprofloxacin resistance status. In Escherichia coli it is well known that the mutation from Ser83Ala in gyrA leads to change from ciprofloxacin susceptibility to ciprofloxacin resistance. However, in N. carnea, N. farcinica, N. flavorosea and N. transvalensis, $\operatorname{Ser}^{83}$ appears not to be critical in this respect; all strains of these species possessed $\mathrm{Ser}^{83}$ but some were susceptible to ciprofloxacin while others were resistant. In contrast, all the strains of $N$. cyriacigeorgica, $N$. nova, and $N$. veterana showed Ser83Ala, but again, some were susceptible to ciprofloxacin while others were resistant. In all the above Nocardia species, no variation was seen in the other position involved in resistance, $\mathrm{Asp}^{87}$. Further, in these Nocardia species, the gyrA positions that affect ciprofloxacin resistance in Mycobacterium tuberculosis - Gly ${ }^{88}$ and Asp ${ }^{94}$ - (Maruri et al., 2012) were all exactly the same; all had both $\mathrm{Gly}^{88}$ and $\mathrm{Asp}^{94}$. Moreover, $\mathrm{Ala}^{90}$, another major position affecting ciprofloxacin resistance in $M$. tuberculosis, was also found in the gyrA gene of $N$. cyriacigeorgica, $N$. nova, and $N$. veterana, while in $N$. carnea, $N$. farcinica, N. flavorosea, and N. transvalensis it was changed to $\operatorname{Ser}^{90}$.

\section{Genetic Determinants of Macrolide and Lincosamide Resistance}

Screening was performed for genes coding for RNA methylases, i.e., $\operatorname{erm}(\mathrm{A}), \operatorname{erm}(\mathrm{B}), \operatorname{erm}(\mathrm{C})$, for efflux pumps, i.e., $m s r(\mathrm{~A}) /(\mathrm{B})$, $\operatorname{msr}(\mathrm{D}), \operatorname{mef}(\mathrm{A} / \mathrm{E})$, and for inactivating enzymes, i.e., ere(A), ere(B), mph(A) (Sutcliffe et al., 1996; Malhotra-Kumar et al., 2005; Lüthje and Schwarz, 2007). The most common was erm(B). This was identified in 59 strains, i.e., in 46 out of 58 strains with erythromycin MICs of $\geq 4 \mathrm{mg} / \mathrm{L}$, and in 13 out of 18 strains with MICs of $\leq 2 \mathrm{mg} / \mathrm{L}$. It showed full similarity to the corresponding gene of Streptococcus pyogenes (AY357120). The next most common determinant was mef(A), which was found in 11 strains [three $N$. carnea strains (with erythromycin MICs of 4,8 , and $16 \mathrm{mg} / \mathrm{L})$, five $N$. farcinica strains $(2,8,16,32$, and $32 \mathrm{mg} / \mathrm{L})$, one $N$. flavorosea strains $(2 \mathrm{mg} / \mathrm{L})$, one $N$. transvalensis strain (4 mg/L), and one Nocardia sp. (1 mg/L)]. This in turn was followed by $m s r(D)$ in four strains: one $N$. farcinica, one N. flavorosea, and two $N$. transvalensis strains with erythromycin MICs of $32,32,16$, and $4 \mathrm{mg} / \mathrm{L}$, respectively. The next most common was erm (A) subclass erm TR, which was found in two strains (one strain each of $N$. farcinica and $N$. transvalensis (erythromycin MICs 32 and $64 \mathrm{mg} / \mathrm{L}$ ).

The resistance genotypes found in combination with erm(B) were: $\operatorname{erm}(\mathrm{B})$ alone in 51 strains, $\operatorname{erm}(\mathrm{B})+\operatorname{erm}(\mathrm{A})$ in one strain, $\operatorname{erm}(\mathrm{B})+m e f(\mathrm{~A})$ in one strain, $\operatorname{erm}(\mathrm{B})+m s r(\mathrm{D})$ in two strains, $\operatorname{erm}(\mathrm{B})+\operatorname{erm}(\mathrm{A})+\operatorname{mef}(\mathrm{A})$ in one strain, $\operatorname{erm}(\mathrm{B})+m s r(\mathrm{D})+m e f(\mathrm{~A})$ in two strains, and $m e f(\mathrm{~A})$ alone in 
seven strains. The erm(A) gene in the studied Nocardia species was identical to those expressed in S. pyogenes, S. pneumoniae, and Aerococcus urinae (CP000262, СР002121, and CP002512). The macrolide-efflux gene $m e f(\mathrm{~A})$ and its protein were the same as those seen in S. mitis (DQ304773) but with one amino acid change encoded compared to $S$. pyogenes, $S$. pneumoniae, and S. suis (CP000003, emb FQ312029, CP003922). The macrolidespecific ABC-type efflux carrier gene $m s r(D)$ also coded for one change at the amino acid level with respect to the corresponding genes in S. pyogenes, S. pneumoniae, and S. suis (CP000003, emb FQ312029, CP002465). This involved the replacement of $\mathrm{Glu}^{224}$ (GAA) in $m s r D$ of $S$. pyogenes MGAS10394 (CP000003) by $\mathrm{Gly}^{224}$ (GGA). This erythromycin efflux resistance gene has been described for N. seriolae isolated from yellowtail fish (AB518863-5), but coding for one amino acid difference. None of the Nocardia under study harbored $\operatorname{erm}(\mathrm{C}), m s r(\mathrm{~A}) /(\mathrm{B}), \operatorname{ere}(\mathrm{A})$, $\operatorname{ere}(\mathrm{B})$, or $m p h(\mathrm{~A})$.

Two N. farcinica strains and one N. cyriacigeorgica strain showing linezolid resistance by $E$ test (MICs of $64,>256$, and $>256 \mathrm{mg} / \mathrm{L}$, respectively) and microdilution, did not show the mutations in domain V of the 23S RNA (G2576T or T2504A) described for different Staphylococcus and Enterococcus species (Marshall et al., 2002). Nor did they harbor the $c f r$ gene, which has been reported in some resistant strains of the latter bacteria.

\section{Genetic Determinants of Tetracycline Resistance}

Among the 57 minocycline-resistant strains (MIC $>1 \mathrm{mg} / \mathrm{L}$ ), the ribosomal protection protein gene $\operatorname{tet}(\mathrm{O})$ was the most common determinant, followed by $t e t M$, and then a long way behind by the efflux pump gene tetL (in 27, 13, and 2 strains, respectively). Nineteen SXT-resistant, minocycline-susceptible strains were positive for $\operatorname{tet}(\mathrm{O})$, tet $(\mathrm{M})$, and $\operatorname{tet}(\mathrm{L})(10,6$, and 1 strains). The tet $(\mathrm{O})$ and $\operatorname{tet}(\mathrm{M})$ genes coded for an amino acid sequence identical to those deduced for S. pyogenes MGAS2096 and SP94 (CP000261 and JQ001862), while tet(L) coded for a sequence identical to that reported for N. seriolae, S. suis (AB513330, JQ280448) and Bacillus species. The genotypes (and number of strains) observed were: $\operatorname{tet}(\mathrm{O})(25), \operatorname{tet}(\mathrm{M})(7), \operatorname{tet}(\mathrm{L})(2)$ $\operatorname{tet}(\mathrm{O})+\operatorname{tet}(\mathrm{M})(11)$, and $\operatorname{tet}(\mathrm{O})+\operatorname{tet}(\mathrm{M})+\operatorname{tet}(\mathrm{L})(1) \cdot \operatorname{tet}(\mathrm{E})$, $\operatorname{tet}(\mathrm{G})$, and $\operatorname{tet}(\mathrm{K})(\mathrm{Ng}$ et al., 2001) were not detected.

\section{Discussion}

Nocardia are environmental bacteria that live in soil, water, rotting vegetation, and other organic matter. However, they can cause severe infections in the human respiratory tract, skin, and subcutaneous tissues; on some occasions they may even infect the central nervous system (Brown-Elliott et al., 2006; Minero et al., 2009; Ambrosioni et al., 2010). Like other actinobacteria, they recycle organic material and produce a wide range of biological compounds, including antibiotics (Waksman et al., 2010). In the environmental setting, the presence of antimicrobials can lead to exposed bacteria becoming resistant (Cantón, 2009). Such resistance may involve changes in the permeability of the cell wall to the antimicrobial agent, the loss of its main target, or the increased expression of efflux pumps or inactivating enzymes. Resistance traits can be acquired via mutations in pre-existing chromosomal genes, or via the capture of mobile resistance determinants through horizontal gene transfer (Cantón, 2009; Djordjevic et al., 2013). It is known that resistance genes can move between different parts of the microbial biosphere. Environmental bacteria participate in this by acting as conduits for the spread of antibiotic resistant genes (Martínez, 2008; Roberts, 2011; Stalder et al., 2012; Walsh, 2013). Multidrug resistance is widely considered to be driven via the pressure exerted by the use of antimicrobials. These agents are commonly used in the hospital and community (Woodford et al., 2014). One might expect that environmental bacteria such as Nocardia, with niches in soil, water, and vegetation but which do not make up part of the normal human flora, might be affected by antimicrobials in a different way. However, the present results show that resistance determinants are commonly found in strains of Nocardia sp. causing opportunistic infection in humans.

This work examines a diverse group of Nocardia strains strongly resistant to SXT, the standard treatment for localized and disseminated nocardiosis. Their overall susceptibility profiles were studied by the $E$ test, since difficulties (deficient growth in the microdilution wells, problems reading the endpoints, etc.) are often encountered with the current CLSI recommendation for susceptibility testing of Nocardia, the broth microdilution method. By $E$ test, not yet approved by CLSI, the results are easily evaluated, and a wide range of dilutions of antimicrobials can be examined simultaneously. In Nocardia, susceptibility phenotypes are strongly species-dependent (Schlaberg et al., 2014). Thus, to avoid any bias caused by the species composition of the SXT-resistant group, MICs data were provided separately.

Resistance to SXT may compromise its continued use as a treatment of nocardiosis. In the present work, resistance to sulfonamide and trimethoprim can be partially explained by the presence of $d f r$ genes which encode insensitive DHPS and DFR enzymes, and even better explained by the presence of integrons carrying sul genes. Nearly all of the SXT-resistant strains carried sull as one of the backbone genes of the $3^{\prime}$ conserved segments in class 1 integrons, and three quarters carried sul2 (probably encoded by a small non-conjugative plasmid or a medium-large plasmid), as seen in other genera (Hu et al., 2011). Of the trimethoprim resistance genes reported in Gram-positive bacteria, $d f r A(\mathrm{~S} 1), \operatorname{dfr}(\mathrm{D}), d f r(F)$, $d f r(G)$, and $d f r(K)$ (Perreten et al., 2005; Cattoir et al., 2009), only $d f r A(\mathrm{~S} 1)$ was seen in the present SXT-resistant Nocardia (14.4\%). The $d f r A(\mathrm{~S} 1)$ gene is commonly associated with class 1 integrons. Another mechanism is required to explain the strong trimethoprim resistance shown by the other 64 strains.

The clinically important class 1 integrons, which have the potential to allow for the co-selection of antibiotic resistance, are widely disseminated in environmental settings, associated with plasmids of the IncP-1 incompatibility group. These integrons, and these plasmids, are commonly detected in bacteria living in estuarine waters, wastewater treatment plants, agricultural soils, and the rhizosphere (Henriques et al., 2006a; Stalder et al., 2012). 
Class 2 integrons are described as the second most common, but none was detected in the present work. However, nearly half of the studied strains carried class 3 integrons - which have been little reported in the literature. Of the five types of class 3 integrons described to date, three were detected in clinical enterobacteria (Arakawa et al., 1995; Correia et al., 2003; Poirel et al., 2010; Barraud et al., 2013). Those detected in the present work in Nocardia were identical to those of the environmental bacteria Delftia tsuruhatensis and D. acidovorans (GenBank accession no. EF469602-EF467661), and correspond to the Inc3-4 type (Xu et al., 2007). To date, the presence of class 3 integrons in the clinical setting has been anecdotal, but in environmental ecosystems they might play a role as an important pool of resistance determinants (Stalder et al., 2012).

Two class A $\beta$-lactamases - FAR-1 and AST- 1 - were described in N. farcinica and N. asteroides sensu stricto (Laurent et al., 1999; Poirel et al., 2001), but they cannot explain the complete $\beta$-lactam resistance phenotype. This is the first time that bla $a_{\mathrm{TEM}-1}$ and blaZ, with a ubiquitous distribution in Grampositive and Gram-negative bacteria, have been reported for Nocardia strains $(n=4)$. One of the so-called "big five" carbapenemases, VIM-2, was curiously found in an imipenem-susceptible Nocardia strain. Most of the carbapenemases acquired by bacterial species of clinical importance are thought to have had their origin in environmental bacteria. However, the environment might also be contaminated by resistant bacteria of clinical origin (Woodford et al., 2014). The environmental sources of the bacteria carrying metallo-carbapenemase genes include rivers, other water, and sewage, all of which are also common habitats of Nocardia species. Monitoring carbapenemases in environmental bacteria might help us determine how widely they become disseminated.

High-level aminoglycoside resistance is mediated by AMEs. Curiously, the only AME gene found in the present Nocardia strains $(n=31)$ was aph $\left(3^{\prime}\right)$-IIIa, which inactivates kanamycin and amikacin. It has also been described in Bacillus anthracis, Clostridium perfringens, Enterococcus faecalis, Streptococcus, and Staphylococcus (Perreten et al., 2005; Zarrilli et al., 2005). However, this very same determinant was also present in the amikacin-susceptible strains of Nocardia, and has even been reported in some $E$. faecalis strains with low to intermediate amikacin resistance (Zarrilli et al., 2005). In the aminoglycosideproducing actinomycetes, $16 \mathrm{~S}$ rRNA methylases have been detected that are said to protect the 16S RNA in the 30S ribosome subunit against aminoglycoside (Doi and Arakawa, 2007). None of the Nocardia strains studied in the present work carried any of these genes.

High-level resistance to fluorquinolone in Gram-negative bacteria is produced by mutations in gyrA, the most common mutation site being $\mathrm{Ser}^{83}$, which can change to code for Leu, Trp, Phe, or Tyr. However, in M. tuberculosis, which like Nocardia is an actinomycete, fluorquinolone resistance mainly occurs via modifications at positions 88,90 , or 94 in the QRDR of gyrA (Maruri et al., 2012). In the present Nocardia strains, no association was seen between high-level resistance/non-susceptibility to fluorquinolone and the distribution of mutations in these hot spots. Among the studied Nocardia species, not only the amino acid differences in positions 83 (Ser or Ala) and 90 (Ala or Ser), but also other 20 amino acids of positions 36, 48, 53, 58, 71, 72, 84, 97, 98, 103, 105, 134,141, 146, 147, 151, 152, 153, 154, and 188 (respect E. coli numbering) varied. These GyrA changes were not related to ciprofloxacin susceptibility, but yes to species polymorphism.

Macrolides and lincosamides inhibit the synthesis of protein by binding to the $50 \mathrm{~S}$ ribosomal unit, and therefore block peptide bond formation and/or translation. The dimethylation of the adenine residue in the $23 \mathrm{~S}$ rRNA produces a conformational change in the ribosome leading to a constitutive or inducible macrolide but not linezolid - resistance phenotype (Roberts, 2011). The most common bacterial rRNA methylase is ErmB, which confers high MICs for macrolides; this was seen in the present work for $77.6 \%$ of all the Nocardia strains examined. $\operatorname{erm}(\mathrm{B})$ is carried on either conjugative transposons, such as those of the Tn916 family (in chromosome or plasmids), or in non-conjugative transposons such as Tn917. It is well known that $\operatorname{Tn} 916$ and its relatives (Tn1545, Tn3703, Tn3704, Tn3872, Tn6002, and Tn6003), as well as newly found elements, often carry other resistance determinants, including tet $(\mathrm{M})$, tet $(\mathrm{O})$, and $m e f(\mathrm{~A})-m s r(\mathrm{D})$, among others (Brenciani et al., 2007; Cochetti et al., 2008; Roberts, 2011).

The second most commonly detected resistance mechanism in the present Nocardia was related to the possession of mef(A), which was detected in some $14.4 \%$ of the studied strains. Both $m e f(\mathrm{~A})$ and $m e f(\mathrm{E})$ code for an active macrolide efflux pump mediated by the $\mathrm{ABC}$ transporter, the transmembrane domains of which are encoded by the mef A/E genes, and the ATP-binding domains by $m s r(\mathrm{D})$ (Malhotra-Kumar et al., 2005). mef(A) and $m s r(\mathrm{D})$ are always linked in other Gram-positive bacteria (Roberts, 2011), but, in the present work, two of the four $m s r(\mathrm{D})$-positive Nocardia strains detected showed no such combination. Regarding the three linezolid-resistant Nocardia strains, the described mutations of 23S (G2576T or T2504) or the $c f r$ gene were no detected (Marshall et al., 2002).

The same Tn916 family mobile elements that carry the major macrolide resistance determinants also carry tetracycline determinants (Roberts, 2005, 2011), as seen in S. pyogenes, in which the strongly linked erm(B) and tet(M) genes are carried on highly variable and complex genetic elements (Brenciani et al., 2004, 2007; Cochetti et al., 2008; Roberts, 2011). However, the association between these determinants was quite different in Nocardia. The combination $\operatorname{erm}(\mathrm{B})+\operatorname{tet}(\mathrm{O})$ appeared nearly twice as often as $\operatorname{erm}(\mathrm{B})+\operatorname{tet}(\mathrm{M})$ (33 strains compared to 18). $\operatorname{erm}(\mathrm{B})+\operatorname{tet}(\mathrm{O})+\operatorname{tet}(\mathrm{M})$ appeared in 12 strains.

The presence of several resistance determinants - VIM-2, $a p h\left(3^{\prime}\right)-I I I a, \operatorname{erm}(\mathrm{B}), \operatorname{mef}(\mathrm{A}), \operatorname{tet}(\mathrm{O}), \operatorname{tet}(\mathrm{M})$ - in strains susceptible to the involved antimicrobials, may mean that, in these strains, these determinants are silent genes or may lack functionality. In environmental bacteria, the detection of a specific resistant determinant with susceptible phenotype, could be suggested a different role of the resistance mechanism to the "weaponshield" (Martínez, 2008), or some failure or difference in their acquisition that affect their expression.

The clinical SXT-resistant Nocardia strains analyzed here were very similar with regard to their antimicrobial resistance traits, 
perhaps the result of a common genetic platform. Although sulfonamides are synthetic compounds and their use in human infections has been reduced for decades, sulfonamide resistance determinants have been shown to persist in bacteria isolated from humans, animals, food, and the environment. sul-carrying plasmids form a pool of resistance genes that can be transferred to human and non-human reservoirs, as observed in this work for the SXT-resistant Nocardia strains. These findings are of some concern.

\section{Conclusion}

This is the first work to describe in Nocardia the presence of several genetic determinants frequently involved

\section{References}

Ambrosioni, J., Lew, D., and Garbino, J. (2010). Nocardiosis: updated clinical review and experience at a tertiary center. Infection 38, 89-97. doi: 10.1007/s15010-009-9193-9

Arakawa, Y., Murakami, M., Suzuki, K., Ito, H., Wacharotayankun, R., Ohsuka, S. et al. (1995). A novel integron-like element carrying the metallo-betalactamase gene blaIMP. Antimicrob. Agents Chemother. 39, 1612-1615. doi: 10.1128/AAC.39.7.1612

Argudín, M. A., Tenhagen, B. A., Fetsch, A., Sachsenröder, J., Käsbohrer, A., Schroeter, A., et al. (2011). Virulence and resistance determinants of German Staphylococcus aureus ST398 isolates from non-human sources. Appl. Environ. Microbiol. 77, 3052-3060. doi: 10.1128/AEM.02260-10

Azevedo, J. S., Araújo, S., Oliveira, C. S., Correia, A., and Henriques, I. (2013) Analysis of antibiotic resistance in bacteria isolated from the surface microlayer and underlying water of an estuarine environment. Microb. Drug Resist. 19, 64-71. doi: 10.1089/mdr.2012.0084

Barraud, O., Casellas, M., Dagot, C., and Ploy, M. C. (2013). An antibioticresistant class 3 integron in an Enterobacter cloacae isolate from hospital effluent. Clin. Microbiol. Infect. 19, E306-E308. doi: 10.1111/1469-0691. 12186

Bou, G., and Martínez-Beltrán, J. (2000). Cloning, nucleotide sequencing, and analysis of the gene encoding an AmpC beta-lactamase in Acinetobacter baumannii. Antimicrob. Agents Chemother. 44, 428-432. doi: 10.1128/AAC.44.2.428432.2000

Brenciani, A., Bacciaglia, A., Vecchi, M., Vitali, L. A., Varaldo, P. E., and Giovanetti, E. (2007). Genetic elements carrying erm(B) in Streptococcus pyogenes and association with tet(M) tetracycline resistance gene. Antimicrob. Agents Chemother. 51, 1209-1216. doi: 10.1128/AAC.01484-06

Brenciani, A., Ojo, K. K., Monachetti, A., Menzo, S., Roberts, M. C., Varaldo, P. E., et al. (2004). Distribution and molecular analysis of mef(A)-containing elements in tetracycline-susceptible and -resistant Streptococcus pyogenes clinical isolates with efflux-mediated erythromycin resistance. J. Antimicrob. Chemother. 54, 991-998. doi: 10.1093/jac/dkh481

Brown-Elliott, B. A., Biehle, J., Conville, P. S, Cohen, S., Saubolle, M., Sussland, D. et al. (2012). Sulfonamide resistance in isolates of Nocardia spp. from a US multicenter survey. J. Clin. Microbiol. 50, 670-672. doi: 10.1128/JCM.06243-11

Brown-Elliott, B. A., Brown, J. M., Conville, P. S., and Wallace, R. J. Jr. (2006). Clinical and laboratory features of the Nocardia spp. based on current molecular taxonomy. Clin. Microbiol. Rev. 19, 259-282. doi: 10.1128/CMR.19.2.259282.2006

Byrne-Bailey, K. G., Gaze, W. H., Kay, P., Boxall, A. B., Hawkey, P. M., and Wellington, E. M. (2009). Prevalence of sulfonamide resistance genes in bacterial isolates from manured agricultural soils and pig slurry in the United Kingdom. Antimicrob. Agents Chemother. 53, 696-702. doi: 10.1128/AAC.00652-07

Cantón, R. (2009). Antibiotic resistance genes from the environment: a perspective through newly identified antibiotic resistance mechanisms in the in antimicrobial resistance in clinical bacteria. The extent of the environmental resistome, and the recruitment of multiple resistance genes from it, should be further studied.

\section{Acknowledgments}

This study was presented at the 54th Interscience Conference on Antimicrobial Agents and Chemotherapy, ICAAC2014, Washington, DC, USA. We thank Adrian Burton for editing and language assistance (http://physicalevidence.es/ english/welcome). We are very grateful to all persons who took part in this study, and to the sample providers.

clinical setting. Clin. Microbiol. Infect. 15(Suppl. 1), 20-25. doi: 10.1111/j.14690691.2008.02679.x

Cattoir, V., Huynh, T. M., Bourdon, N., Auzou, M., and Leclercq, R. (2009). Trimethoprim resistance genes in vancomycin-resistant Enterococcus faecium clinical isolates from France. Intern. J. Antimicrob. Agents 34, 390-392. doi: 10.1016/j.ijantimicag.2009.06.013

Cattoir, V., Poirel, L., Rotimi, V., Soussy, C. J., and Nordmann, P. (2007). Multiplex PCR for detection of plasmid-mediated quinolone resistance qnr genes in ESBL-producing enterobacterial isolates. J. Antimicrob. Chemother. 60, 394397. doi: $10.1093 / \mathrm{jac} / \mathrm{dkm} 204$

Chen, Y., Zhou, Z., Jiang, Y., and Yu, Y. (2011). Emergence of NDM-1-producing Acinetobacter baumannii in China. J. Antimicrob. Chemother. 66, 1255-1259. doi: $10.1093 / \mathrm{jac} / \mathrm{dkr} 082$

Chouchani, C., El Salabi, A., Marrakchi, R., Ferchichi, L., and Walsh, T. R. (2012) First report of mefA and msrA/msrB multidrug efflux pumps associated with blaTEM-1 $\beta$-lactamase in Enterococcus faecalis. Int. J. Infect. Dis. 16, 104-109. doi: 10.1016/j.ijid.2011.09.024

Clark, N. C., Olsvik, O., Swenson, J. M., Spiegel, C. A., and Tenover, F. C. (1999). Detection of a streptomycin/spectinomycin adenylyltransferase gene (aadA) in Enterococcus faecalis. Antimicrob. Agents Chemother. 43, 157-160.

Clinical Laboratory Standards Institute [CLSI]. (2011). Susceptibility Testing of Mycobacteria, Nocardiae, and Other Aerobic Actinomycetes. Approved Standard-M24-A2, 2nd Edn, Vol. 31. Wayne, PA: Clinical and Laboratory Standards Institute.

Cochetti, I., Tili, E., Mingoia, M., Varaldo, P. E., and Montanari, M. P. (2008). erm(B)-carrying elements in tetracycline-resistant pneumococci and correspondence between Tn1545 and Tn6003. Antimicrob. Agents Chemother. 52, 1285-1290. doi: 10.1128/AAC.01457-07

Correia, M., Boavida, F., Grosso, F., Salgado, M. J., Lito, L. M., Melo Cristino, J., et al. (2003). Molecular characterization of a new class 3 integron in Klebsiella pneumoniae. Antimicrob. Agents Chemother. 47, 2838-2843. doi: 10.1128/AAC.47.9.2838-2843.2003

Dale, G. E., Langen, H., Page, M. G., Then, R. L., and Stüber, D. (1995). Cloning and characterization of a novel, plasmid-encoded trimethoprim-resistant dihydrofolate reductase from Staphylococcus haemolyticus MUR313. Antimicrob. Agents Chemother. 39, 1920-1924. doi: 10.1128/AAC.39.9.1920

Deresinski, S. (2012). Nocardia resistant to trimethoprim-sulfamethoxazole? Maybe not. Clin. Infect. Dis 55, iii-iv.

Djordjevic, S. P., Stokes, H. W., and Chowdhury, R. P. (2013). Mobile elements, zoonotic pathogens and commensal bacteria: conduits for the delivery of resistance genes into humans, production animals and soil microbiota. Front. Microbiol. 4:86. doi: 10.3389/fmicb.2013.00086

Doi, Y., and Arakawa, Y. (2007). 16S ribosomal RNA methylation: emerging resistance mechanism against aminoglycosides. Clin. Infect. Dis. 45, 88-94. doi: $10.1086 / 518605$

Ellington, M. J., Kistler, J., Livermore, D. M., and Woodford, N. (2007). Multiplex PCR for rapid detection of genes encoding acquired metallo-beta-lactamases. J. Antimicrob. Chemother. 59, 321-322. doi: 10.1093/jac/dkl481 
Frye, J. G., Jesse, T., Long, F., Rondeau, G., Porwollik, S., McClelland, M., et al. (2006). DNA microarray detection of antimicrobial resistance genes in diverse bacteria. Int. J. Antimicrob. Agents 27, 138-151. doi: 10.1016/j.ijantimicag.2005.09.021

Glupczynski, Y., Berhin, C., Janssens, M., and Wauters, G. (2006). Determination of antimicrobial susceptibility patterns of Nocardia spp. from clinical specimens by $E$ test. Clin. Microbiol. Infect. 12, 905-912. doi: 10.1111/j.14690691.2006.01460.x

Gosia, K. K., Boerlin, P., Janecko, N., Reid-Smith, R. J., and Jardine, C. (2009). Antimicrobial resistance in Escherichia coli isolates from swine and wild small mammals in the proximity of swine farms and in natural environments in Ontario, Canada. Appl. Environ. Microbiol. 75, 559-566. doi: 10.1128/AEM.01821-08

Henriques, I. S., Fonseca, F., Alves, A., Saavedra, M. J., and Correia, A. (2006a). Occurrence and diversity of integrons and $\beta$-lactamase genes among ampicillinresistant isolates from estuarine waters. Res. Microbiol. 157, 938-947. doi: 10.1016/j.resmic.2006.09.003

Henriques, I. S., Moura, A., Alves, A., Saavedra, M. J., and Correia, A. (2006b). Analyzing diversity among $\beta$-lactamase encoding genes in aquatic environments. FEMS Microbiol. Ecol. 56, 418-442. doi: 10.1111/j.15746941.2006.00073.x

Hu, L. F., Chang, X., Ye, Y., Wang, Z. X., Shao, Y. B., Shi, W., et al. (2011). Stenotrophomonas maltophilia resistance to trimethoprim/sulfamethoxazole mediated by acquisition of sul and $\operatorname{dfrA}(\mathrm{S} 1)$ genes in a plasmidmediated class 1 integron. Int. J. Antimicrob. Agents 37, 230-234. doi: 10.1016/j.ijantimicag.2010.10.025

Huovinen, P. (2001). Resistance to trimethoprim-sulfamethoxazole. Clin. Infect. Dis. 32, 1608-1614. doi: 10.1086/3 20532

Huovinen, P., Huovinen, S., and Jacoby, G. A. (1988). Sequence of PSE-2 $\beta$-lactamase. Antimicrob. Agents Chemother. 32, 134-136. doi: 10.1128/AAC.32.1.134

Ishikawa, S. (2011). Simultaneous PCR detection of multiple classes of integron integrase genes for determining the presence of multidrug-resistant bacteria in environmental samples. Curr. Microbiol. 62, 1677-1681. doi: 10.1007/s00284011-9913-5

Kehrenberg, C., and Schwarz, S. (2006). Distribution of florfenicol resistance genes fexA and cfr among chloramphenicol-resistant Staphylococcus isolates. Antimicrob. Agents Chemother. 50, 1156-1163. doi: 10.1128/AAC.50.4.11561163.2006

Kim, H. B., Park, C. H., Kim, C. J., Kim, E. C., Jacoby, G. A., and Hooper, D. C. (2009). Prevalence of plasmid-mediated quinolone resistance determinants over a 9-year period. Antimicrob. Agents Chemother. 53, 639-645. doi: 10.1128/AAC.01051-08

Laurent, F., Poirel, L., Naas, T., Chaibi, E. B., Labia, R., Boiron, P., et al. (1999). Biochemical-genetic analysis and distribution of FAR-1, a class A beta-lactamase from Nocardia farcinica. Antimicrob. Agents Chemother. 43, 1644-1650.

López, M., Kadlec, K., Schwarz, S., and Torres, C. (2012). First detection of the staphylococcal trimethoprim resistance gene dfrK and the dfrK-carrying transposon Tn559 in Enterococci. Microb. Drug Resist. 18, 13-18. doi: $10.1089 / \mathrm{mdr} .2011 .0073$

Lüthje, P., and Schwarz, S. (2007). Molecular basis of resistance to macrolides and lincosamides among staphylococci and streptococci from various animal sources collected in the resistance monitoring program BfT-GermVet. Int. J. Antimicrob. Agent 29, 528-535. doi: 10.1016/j.ijantimicag.2006. 12.016

Malhotra-Kumar, S., Lammens, C., Piessens, J., and Goossens, H. (2005). Multiplex PCR for simultaneous detection of macrolide and tetracycline resistance determinants in streptococci. Antimicrob. Agents Chemother. 49, 4798-4800. doi: 10.1128/AAC.49.11.4798-4800.2005

Marshall, S. H., Donskey, C. J., Hutton-Thomas, R., Salata, R. A., and Rice, L. B. (2002). Gene dosage and linezolid resistance in Enterococcus faecium and Enterococcus faecalis. Antimicrob. Agents Chemother. 46, 3334-3336. doi: 10.1128/AAC.46.10.3334-3336.2002

Martínez, J. L. (2008). Antibiotics and antibiotic resistance genes in natural environments. Science 321, 365-367. doi: 10.1126/science.11 59483
Maruri, F., Sterling, T. R., Kaiga, A. W., Blackman, A., van der Heijden, Y. F., Mayer, C., et al. (2012). A systematic review of gyrase mutations associated with fluoroquinolone-resistant Mycobacterium tuberculosis and a proposed gyrase numbering system. J. Antimicrob. Chemother. 67, 819-831. doi: $10.1093 / \mathrm{jac} / \mathrm{dkr} 566$

Minero, M. V., Marín, M., Cercenado, E., Rabadán, P. M., Bouza, E., and Muñoz, P. (2009). Nocardiosis at the turn of the century. Medicine 88, 250-261. doi: 10.1097/MD.0b013e3181afa1c8

Ng, L. K., Martin, I., Alfa, M., and Mulvey, M. (2001). Multiplex PCR for the detection of tetracycline resistant genes. Mol. Cell. Probes 15, 209-215. doi: 10.1006/mcpr.2001.0363

Ouellette, M., Bissonnette, L., and Roy, P. H. (1997). Precise insertion of antibiotic resistance determinants into Tn21-like transposons: nucleotide sequence of the OXA-1 $\beta$-lactamase gene. Proc. Natl. Acad. Sci. U.S.A. 84, 7378-7382. doi: 10.1073/pnas.84.21.7378

Park, C. H., Robicsek, A., Jacoby, G. A., Sahm, D., and Hooper, D. C. (2006) Prevalence in the United States of aac(6')-Ib-cr encoding a ciprofloxacinmodifying enzyme. Antimicrob. Agents Chemother. 50, 3953-3995. doi: 10.1128/AAC.00915-06

Perreten, V., Vorlet-Fawer, L., Slickers, P., Ehricht, R., Kuhnert, P. and Frey, J. (2005). Microarray-based detection of 90 antibiotic resistance genes of gram-positive bacteria. J. Clin. Microbiol. 43, 2291-2302. doi: 10.1128/JCM.43.5.2291-230 2.2005

Petti, C. A., Bosshard, P. P., Brandt, M. E., Clarridge, J. E., Feldblyum, T. V., Foxall, P., et al. (2008). Interpretive Criteria for Identification of Bacteria and Fungi by DNA Target Sequencing, Vol. 28, Approved Guidelines. Wayne, PA: Clinical and Laboratory Standards Institute.

Poirel, L., Carattoli, A., Bernabeu, S., Bruderer, T., Frei, R., and Nordmann, P. (2010). A novel IncQ plasmid type harbouring a class 3 integron from Escherichia coli. J. Antimicrob. Chemother. 65, 1594-1598. doi: $10.1093 / \mathrm{jac} / \mathrm{dkq} 166$

Poirel, L., Laurent, F., Naas, T., Labia, R., Boiron, P., and Nordmann, P. (2001). Molecular and biochemical analysis of AST-1, a class A beta-lactamase from Nocardia asteroides sensu stricto. Antimicrob. Agents Chemother. 45, 878-882. doi: 10.1128/AAC.45.3.878-882.2001

Roberts, M. C. (2005). Update on acquired tetracycline resistance genes. FEMS Microbiol. Lett. 245, 195-203. doi: 10.1016/j.femsle.2005 02.034

Roberts, M. C. (2011). Environmental macrolide-lincosamide-streptogramin and tetracycline resistant bacteria. Front. Microbiol. 2:40. doi: $10.3389 /$ fmicb. 2011.00040

Robicsek, A., Strahilevitz, J., Sahm, D. F., Jacoby, G. A., and Hooper, D. C. (2006). Qnr prevalence in ceftazidime-resistant Enterobacteriaceae isolates from the United States. Antimicrob. Agents Chemother. 50, 2872-2874. doi: 10.1128/AAC.01647-05

Rodriguez-Nava, V., Couble, A., Devulder, G., Flandrois, J. P., Boiron, P., and Laurent, F. (2006). Use of PCR-restriction enzyme pattern analysis and sequencing database for hsp65 gene-based identification of Nocardia species. J. Clin. Microbiol. 44, 536-546. doi: 10.1128/JCM.44.2.536-546.2006

Schlaberg, R., Fisher, M. A., and Hanson, K. E. (2014). Susceptibility profiles of Nocardia isolates based on current taxonomy. Antimicrob. Agents Chemother. 58, 780-795. doi: 10.1128/AAC.01531-13

Schmitz, F.-J., Fluit, A. C., Gondolf, M., Beyraua, R., Lindenlauf, E., Verhoef, J., et al. (1999). The prevalence of aminoglycoside resistance and corresponding resistance genes in clinical isolates of staphylococci from 19 European hospitals. J. Antimicrob. Chemother. 43, 253-259. doi: 10.1093/jac/4 3.2.253

Stalder, T., Barraud, O., Casellas, M., Dagot, C., and Ploy, M. C. (2012). Integron involvement in environmental spread of antibiotic resistance. Front. Microbiol. 3:119. doi: 10.3389/fmicb.2012.00119

Su, J., Shi, L., Yang, L., Xiao, Z., Li, X., and Yamasaki, S. (2006). Analysis of integrons in clinical isolates of Escherichia coli in China during the last six years. FEMS Microbiol. Lett. 254, 75-80. doi: 10.1111/j.1574-6968.2005.0 0025.x

Sutcliffe, J., Grebe, T., Tait-Kamradt, A., and Wondrack, L. (1996). Detection of erythromycin-resistant determinants by PCR. Antimicrob. Agents Chemother. $40,2562-2566$. 
Uhde, K. B., Pathak, S., McCullum, I. Jr., Jannat-Khah, D. P., Shadomy, S. V., Dykewicz, C. A., et al. (2010). Antimicrobial-resistant Nocardia isolates, United States, 1995-2004. Clin. Infect. Dis. 51, 1445-1448. doi: 10.1086/657399

Vakulenko, S. B., Donabedian, S. M., Voskresenskiy, A. M., Zervos, M. J., Lerner, S. A., and Chow, J. W. (2003). Multiplex PCR for detection of aminoglycoside resistance genes in enterococci. Antimicrob. Agents Chemother. 47, 1423-1426. doi: 10.1128/AAC.47.4.1423-1426.2003

Vera-Cabrera, L., Ortiz-Lopez, R., Elizondo-Gonzalez, R., and OcampoCandiani, J. (2013). Complete genome sequence analysis of Nocardia brasiliensis HUJEG-1 reveals a saprobic lifestyle and the genes needed for human pathogenesis. PLoS ONE 8:e65425. doi: 10.1371/journal.pone.0065425

Waksman, S. A., Schatz, A., and Reynolds, D. M. (2010). Production of antibiotic substances by actinomycetes. Ann. N. Y. Acad. Sci. 1213, 112-124. doi: 10.1111/j.1749-6632.2010.05861.x

Walsh, F. (2013). Investigating antibiotic resistance in non-clinical environments. Front. Microbiol. 4:19. doi: 10.3389/fmicb.2013.00019

Welsh, O., Vera-Cabrera, L., and Salinas-Carmona, M. C. (2013). Current treatment for Nocardia infections. Expert Opin. Pharmacother. 14, 2387-2398. doi: $10.1517 / 14656566.2013 .842553$

Woodford, N., Wareham, D. W., Guerra, B., and Teale, C. (2014). Carbapenemaseproducing Enterobacteriaceae and non-Enterobacteriaceae from animals and the environment: an emerging public health risk of our own making? J. Antimicrob. Chemother. 69, 287-291. doi: 10.1093/jac/dkt392

$\mathrm{Xu}, \mathrm{H}$., Davies, J., and Miao, V. (2007). Molecular characterization of class 3 integrons from Delftia spp. J. Bacteriol. 189, 6276-6283. doi: 10.1128/JB.00 348-07

Zarrilli, R., Tripodi, M. F., Di Popolo, A., Fortunato, R., Bagattini, M., Crispino, M., et al. (2005). Molecular epidemiology of high-level aminoglycoside-resistant enterococci isolated from patients in a university hospital in southern Italy. J. Antimicrob. Chemother. 56, 827-835. doi: 10.1093/jac/dki347

Conflict of Interest Statement: The authors declare that the research was conducted in the absence of any commercial or financial relationships that could be construed as a potential conflict of interest.

Copyright (c) 2015 Valdezate, Garrido, Carrasco, Villalón, Medina-Pascual and Saéz-Nieto. This is an open-access article distributed under the terms of the Creative Commons Attribution License (CC BY). The use, distribution or reproduction in other forums is permitted, provided the original author(s) or licensor are credited and that the original publication in this journal is cited, in accordance with accepted academic practice. No use, distribution or reproduction is permitted which does not comply with these terms. 